\title{
AMERICAN MYTH VALUES IN OUR TOWN PLAY BY THORNTON WILDER (A STUDY OF MYTHOLOGY)
}

\author{
Uup Gufron \\ Program of English Education, Faculty of Language and Art, University of Indraprasta PGRI \\ Jalan Nangka No. 58 C Tanjung Barat, Jagakarsa, South Jakarta 12530 \\ media.madani@yahoo.com
}

\begin{abstract}
This research aims to prove that American people really still believe in the myth during the early twentieth-century. The writer finds many historical data and uses an analytic descriptive method for literary research. To support this research, two theories are employed; they are mythology theory and literary sociology approach. Thornton Wilder describes portrait of the American society that still believed in the myths in his best play entitled Our Town (1983). They lived in fictional small town namely Grover's Corner. In their daily activities, they kept firmly the belief in the myths without missing the faith to religion. They realized that there were many positive things and goodness in every myth. The central values on the play are talking about myths in three phases of life such as childhood, marriage and death. All of them are talking about myths of days, months, weather, time, color, and ghost. In every belief of the myths, all of them contain how we can choose a good and bad one in facing problem. We should not do what the belief forbids. If we disobey them, -as in myth told- we will get some bad effect.
\end{abstract}

Key Words: myth, America, Wilder, play

\section{ABSTRAK}

Penelitian ini bertujuan untuk membutikan bahwa warga Amerika masih mempercayai mitos di awal abad 20-an. Penulis telah menemukan banyak data historis dan menggunakan metode deskriptif analitik untuk penelitian pustaka. Untuk mendukung penelitian ini, terdapat dua teori yang digunakan, yaitu teori mitologi dan pendekatan kajian sosiologi. Thornton Wilder menjelaskan sebuah gambaran warga Amerika yang masih mempercayai mitos dalam sebuah drama yang berjudul Our Town (1983). Mereka tinggal di kota kecil khayalan bernama Grover's Corner. Dalam kegiatan sehari-hari, mereka tetap menjaga keyakinan akan agama. Mereka sadar bahwa terdapat banyak hal positif dan kebaikan dalam setiap mitos. Nilai utama pada drama adalah membahas persoalan mitos dalam tiga fase kehidupan, yaitu masa kanak-kanak, pernikahan, dan kematian. Kesemuanya berbicara mengenai mitos tentang hari, bulan, cuaca, waktu, warna dan hantu. Dalam setiap kepercayaan terhadap mitos, semuanya menjelaskan cara untuk memilih hal-hal baik atau buruk dalam menghadapi masalah. Kita tidak boleh melakukan sesuatu yang berseberangan dengan keyakinan. Jika kita melanggar aturanaturan tersebut, seperti apa yang dikatakan oleh suatu mitos, kita akan memperoleh pengaruh yang buruk.

Kata Kunci: mitos, Amerika, Wilder, drama 


\section{INTRODUCTION}

Literature cannot be dissociated with reality. It relates to the social culture. "When a playwright tries to create a literary work, there are many ideas in his mind that he wants to transfer to the readers or audiences" (Teeuw, 2003:10). Message of literary work that will be transferred, of course, comes from his experience, learning from history, and result of communication with society. Many playwrights conduct this matter, as well as Thornton Wilder. $\mathrm{He}$, who was the notable American playwright in the twentieth-century, wrote some ideas of his fiction on the basis of life reality. His best play entitled Our Town was a work describing about American society life in the early twentieth-century (1901-1913). Wilder tried to reflect the cycle of American traditional life that is still believed in the myth by generations.

In that play, Wilder depicted a fictional small town as American society that was named Grover's Corners, New Hampshire. Its society lived happily and harmoniously, even though they were lower middle class, a little professional people, and ten percents are uneducated labours. Eighty five percents of them were Protestants, twelve percents were Catholic, and the rest were indifferent. "Religious people at that moment had also seen a greater openness to interposition of the supernatural in everyday life" (Goff and Harvey, 1961:15).

"Myth trusted by the American society stems from the Indians and earliest Americans" (Robinson and Wilson, 1978:209). It is trusted by generations; even it becomes eroded because of industrialization and modernization. American society itself actually has many myths. Meanwhile, myth implied in Our Town just represented the small share from all myths in the early of twentieth-century. The myths were the beliefs that did not include values of religion, but they believed in it as well as religion. They assumed that if they did not believe it, they would be fatal.

The stories of mythology in Our Town have many meanings. According to Mircea Eliade, the story of deities and ape-man has given people thinking frameworks, admired values, and archetypes. Archetypes are the natural psychical behaviour patterns that universally are not conscious and it is in every potential human beings. The myth functions as a model for human activity, society, wisdom, and knowledge. Meanwhile, mythology is used for the entire body of myths that are found in a given tradition. It is used as a term for the study of myths.

In this life, wherever we are, life is constructed with three phases. Thomas E Porter, from The University of Detroit, says in Myth and Modern American Drama that three phases are the basic structure in the progress of universal human experience. First is birth and growth (childhood); second is marriage; and third is death. These events are unique in life of the individual. Our Town presents those events. They become the substructure in the scene of this drama. They form the basic pattern for every life. Thus, the pattern is both linear for the individual and cyclical for the community. The structure combines both these aspect (Porter, 1969).

The story theme of the drama centrally talks about values of Christian religion and myth that implicate to individual, family, and society life. This drama also represents the cultural social documentation, because many myth behaviours are revealed in that drama. The myth behaviours are described as seen in the situation of social life in America in the early twentieth-century. 
So the writer was very interested in studying it based on the cultural perspective, or anthropological study.

Later, choosing this object is also because the drama is the Wilder's masterwork. Our Town had become one of the most popular plays produced in the $20^{\text {th }}$ century. It was filmed in 1940. Wilder got the Pulitzer Prize in 1938 with that play. To Wilder himself, that prize was not for the first time, two other masterpieces also got the same prize, both were the novel entitled The Bridge of San Luis Rey in 1928 and drama entitled The Skin of Our Teeth in 1943. Our Town firstly was performed in New York in February 1938. At the first night staging, audience was exiting and responding with the model of play, because in the staging it was performed without curtain and scenery. Since that time, the audience had grown accustomed to the easy informality of the Stage Manager as he introduced each scene, interrupted the action with commentary, took the part of several minor characters, improvised scenery, and spook the epilogue. So that Our Town became one of the most successful plays in the modern America Theatre (Carlsen, 1937).

The objective of this research is to prove the using of Mircea Eliade's theory of mythology concerning with the society myth. This study also aims to know American myth values during the early twentieth-century. The significance of this research is to give information to others about American myths, so that it can stimulate the development of literary studies. Focus of the problem on this research is about American mythology. To reach it, the writer will limit the study to myth scope trusted by American society in Our Town play concerning the myth of childhood, marriage and death. It will be correlated with social reality life during the early twentieth-century. Then, the writer tries to describe the historical data that is concerning with life behavior and myth values trusted by American society by generation, particularly in the early twentieth-century, so that it can be found the relation between fictional life and reality. Writer also explains the American life values that are consisted in that play.

To know the term "mythology", we firstly need to define the meaning of word "myth". This word is taken from the Greek "muthos". According to etymology, it originally means "word", "discourse", or "speech" (Coupe, 1997: 97). Mythology as science is the study of myth and body of myths belonging a particular religious tradition. Mythology can be used to denote the myths that have made a tradition in some society. Moreover, mythology, like in the other discipline, has a study limitation, scope, systematic, objective, and significance. Beside that, "Mythology has correlated to the politics, economics, literature, social, culture, etc." (Zeffri, 1998: 8).

Mythology as a science discipline had grown up fatly in the last ninetieth-century. Even though people believe myth itself for hundreds of century ago, but it was decelerated as study discipline in the last nineteenth century.

According to Eliade (1960), myth is a symbol that is put on the story. Myth is not only a description or sign, but it is a whole description that is revealed in a tale. It talks about tale of deities, ancestor or hero, and supernatural. Myth can be defined as anything that was contrary to the reality. Accordingly, Eliade (1960:23) describes about myth as follows:

"What exactly is a myth? In the language current during the nineteenth century, a myth meant anything that was opposed to reality: 
the creation of Adam, or the invisible man, no less than the history of the world as described by the Zulus, or the Theogony of Hesiod -these were all myth."

The myth, whatever it nature, is always a precedent and an example, not only for people's action including sacred or profane, but also as an honor to the situation where his nature places him. The precedent is for the expressions of reality as a whole. Primitive society had ever said, "We must do what the gods did in the beginning.

It is true to say that myth reveals more profoundly than any rational experience ever could, the actual structure of the divinity, which transcends all attributes and reconciles all contraries. The mythical experience that is not mere deviation is proved by the fact that it enters into almost all the religious experience of people (Eliade, 1971: 419).

Myth is the cultural and social life basic. For Eliade, myth is the complex cultural reality, so it is difficult to give the limitation in defining it. An Eliade's opinion, myth is the human being effort to communicate between the sacral and profane side of people (Saliba, 1976). Myth becomes the definitive truth and specifies an absolute truth, which cannot be debated. Once told, that is, revealed, the myth becomes and establishes a truth that is absolute. "It is so because it is said that it is so", the ancient people declare to justify the validity of their sacred history and religious traditions. The myth proclaims the appearance of a new cosmic situation or of a primordial event (Eliade, 1959: 95). Myth defines the mystery screen from primordial events, which still narrated and believed nowadays. Myth has a correlation with the time and ritual.
Below is the schema of mythology studies scope taken and resumed from many sources.

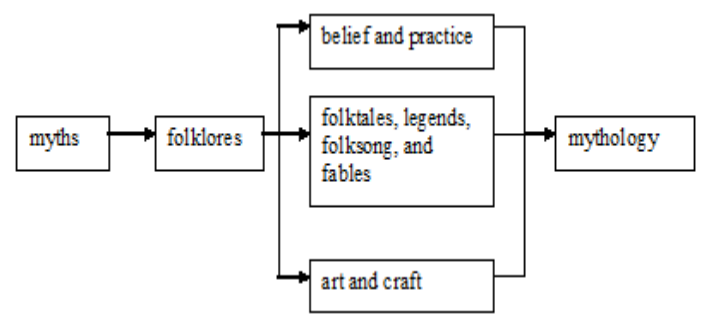

Figure 1. Schema of Mythology Studies

Folktale is a fictional narrative tale. Legend usually characterizes a traditional tale thought to have a historical basis, as in the legends of King Arthur or Robin Hood. The legend sometimes is named as ballad and romance. Folksong is a traditional song verse exhibits characteristic shared by other kind of folklore. Fable is same like the folklore, but the difference is it personifies animals or natural objects.

To identify some works whether it was literary work or not, it depended on the spirit or hope and overview of the readers or audiences. Moreover, what something in some traditional places was called as literature, but in the other place might not be named a literature. If the readers assume and understand that the work was literature, it would be understood as literary work.

From many definitions, the writer here just wants to take the conclusion that the term "literature" can be said as a special type of writing whose values lie in beauty of form or emotional effect. This is maybe a similarity from the definitions above, because the word "literature" is derived from Latin litteratura, or Greek littera and gramma that have a meaning letter (Teeuw, 2003:34).

Literary sociology is one of the branches of the literary research. This research, according to Endraswara 
(2004), is a reflective one. It means that social life will be raced by the creation of the literary work. The literature is not only the effect of social causes but also the causes of the social effect. The literary sociology research can relate to the causality influence between sociology and literature. Both of them can influence each other, and finally it is interesting for the researcher to study them. This research generally is conducted in order to see that literary work is the mirror of society life. Hence, primary assumption from this research is the creation of literature that does not in social blank. A successful literary work is something that reflected its epoch.

Sociological theory, or here called literary sociology, maintains that the literary work cannot be separated from the social context in which it was created. Literature reflects society and derives its essential existence and significance from the social situation to which it responds (Fokkema and KunneIbsch, 1977). Wolf saw that literary sociology is discipline that has no shape, not to be defined well, consisted of a few empirical studies and a number of general theories, that each other just have the same in the matter which all of them correlated between literature and society.

Playwright creates the literary work based on his experiences, either it is from his esthetics or mind view. When the literary work is written, he does not compromise to the readers about contains of his work. He also does not think what far his literary work will be read by thousands of people. This is a unique thing in literary work. So that, one who read the literary work would be faced many possibilities. When the literary work was in front of the readers, the interpretation possibilities would pop out. The readers may have a different understanding if they viewed the literary work from any different approach. The importance of literary sociology is the concept of mirror. In this case, literature is assumed as mimetic of society.

\section{METHOD}

The method of research used by the writer in this study is qualitative method with the analytic descriptive writing. Its way is describing and analyzing the play as one of the literary work that is a medium to depict the social situation, focuses in American society at the early twentieth-century. The writer tries to answer all the research questions by describing the problems in the study. The writer also tries to analyze the unit of analysis by using any literature references that relate to the study.

In this study, the writer uses the mythology and literary sociology theory to analyze the data. The collected data will be analyzed and discussed into two sections. Each section contains the description and analysis data. Firstly, the study begins by telling the American society myth in Our Town play, and then secondly by telling the American myth history by generation. After that, the data will be explained and analyzed in order to answer the research questions above by qualitative method. The writer analyzes the play by using the dialectic analytic techniques. It is by reading the play and socio-culture of American society in the early twentieth-century to look for research findings based on the story of the play and mythological theory. Then, the writer arranges American society myth values in the $20^{\text {th }}$ century and explains them. At the end, the writer uses a corpus to make easy in this analysis.

Play script is taken from book entitled Three Plays by Thornton Wilder; Our Town, The Skin of Our Teeth, The Matchmaker illustrated by Alex Tsao with a preface by the author. The book is published by Bantam Books, New York, 
June 1961. The play script has 64 pages including cover and illustrated stage.

\section{RESULTS AND DISCUSSION}

Our Town is narrated with three acts. The first act is a story about everyday life of town society of Grover's Corners. The second is the act of wedding party of George and Emily, including in it is their love story. The third act is about the death. All acts are run with plot of forward, because the running of exposition, rising action, climax, falling down, and resolution, is developing this play. The plot is the way in which happening are arranged in a literary work. The plot also reveals conflicts that is told, intensified, and revolved during the running of the play.

The author of Our Town, Thornton Wilder, implicitly would like to say to the audiences that in his play there are many myths that are still believed by the American society. Those myths have become the beliefs and superstition. Of course, the beliefs are taken from the American stories such as folktale, legend, folksong, and fables; as we call them as the American folklores. The myth values are as below:

\section{The day of childbirth carries a special import of baby}

The first stage in the cycle of human life is childbirth. It is recognized as period of crisis. In the South America, folk beliefs, costumes, and medicine, associated with childbirth derived from more diverse sources, developed more fully, and endured longer than in any other region of the United State.

According to American superstition, the day of childbirth can make a sign of baby's character. Many people in America still believe that characteristic of the person in the next time can be identified by knowing the birthday, because all days have meanings. The good days are Monday, Tuesday, and Wednesday. The baby born on Monday will have a fair of face. He can be a fair person in the future. Then, if he were born on Tuesday, he would come the person who has a full of grace. In his life he will get many graces from the God. If Wednesday is the day of childbirth, the baby will get a full of love and giving.

But the bad day is like Friday. The baby who was born on Friday will get a woe during his life. The traditional American, but not all, hopes his baby not to be born on Friday. It is because that Friday is presumably of day of the crucifix of Jesus. Then, Thursday will denote a hard worker. Saturday become the baby the person who will go far from his homeland. But if the baby birthday is on Sabbath day, he will be a beautiful or handsome child. The Sabbath day is the Saturday morning, such as in the American superstitions from the rhymes of the folksong said;

Monday's child is fair of face,

Tuesday's child is full of grace,

Wednesday's child is loving and giving,

Thursday's child must work for a living,

Friday's child is full of woe,

Saturday's child has far to go,

But the child that is born on the Sabbath day

Is little and bonny and good and gay.

Tuesday is the third day of the week, taken from name "Tiw" or called "Tyr". He is the son of Odin, the chief Scandinavian deity, which is sometimes named Woden, and then it becomes the name of Wednesday. It was considered neither particularly lucky nor dangerous, but was a time 
of "middleness" or neutrality. Accordingly, James Branch Cabel uses the affecter of all average things in his novel title "Jurgen". Tiw in Scandinavian mythology is the god war and fame, corresponding to the Mars of the Romans, and was prayed to by the heroes for victory.

Emily is one of the people who were born in good day, exactly on Tuesday, February $11^{\text {th }}, 1899$, so she has brilliant and much talent. She is very beautiful, intelligent, diligent, and responsible. She is one of the best students in her school. She likes to study the science of exact. She also has much talent. When she was in Junior High School, she had been a good orator in the class. She was a stamp collector. When she was in Senior High School, she was very active in class organization. In sense of friendship, she always cared to her friend. She did not want her friend leaving her. So she has good characters in Our Town.

In every religion, the day has the important and sacred meanings. We can take the examples like in Christ, Catholic, Jews, and Islam. In Christ and Catholic, Sunday is the holy day to pray in church. For Jewish Saturday is the sacred day as called Sabbath day. But for Moslems, the holy or best day is Friday. Every Moslem prayed together in mosque. They must leave their works when the time to pray is coming. It means that the understanding toward the day depends on their beliefs. It can be sacred one, if they believe that the day is sacred based on their religious teachings.

\section{Groom cannot see his bride before wedding party in church}

In modern America, courtship becomes more a private act conducted in the public world. This intimate business, as it evolved into "dating", increasingly took place in public places removed, by distance and by anonymity, from the sheltering and controlling contexts of home and local community youth increasingly moved their courtship from the private to the public sphere.

In American tradition, no single rite actually associated with love and courtship. Rite is just done in tradition of graduation from high school or college, first apprenticeship in a union, admission to a club, and soon. People do the rite when they celebrate on the wedding day. So, before wedding in the church, there must not be a meeting between the man and girl for some days.

This custom derives from protective custom to prevent brides from being abducted. Stories about the groom distinguished his bride from a group of veiled women continues this theme and seems to be the basis for having several bride maids. In Jewish and Buddhist, this tradition actually is from the religion teachings. If we look at the ritual of wedding, the groom of Jewish and Buddhist are really forbidden to meet the bride. But it is not in Christ's or Catholics.

In American folklore told that the groom is forbidden to see the bride before wedding party in the church. It is actually so difficult to get the main topic in the whole story. This myth is got from the superstitions in American lands. Even though it is not easy to get, here the writer mentions the story containing those superstitions. The story is taken from the myth of the North American Indian titled by The Story of Scarface.

This story is talking about the poor boy namely Scareface who falls 
in love with the beautiful daughter of the tribe chief. At first he gets some troubles to marry her. The tribe chief gives him a dangerous duty to kill some monster. But finally he can make that duty and come back successfully. Then, he marries the lady. Before marriage, the tribe chief forbids him to meet the lady for some days. If it is ignored, the deities according to them will be angry, because it is the rule of the Indian wedding. Beside, the bride will be dead if the groom forces himself to meet her before wedding. In Javanese culture, it is called as "Tradisi Pingit". It can be found in the tradition of Javanese wedding like in Yogyakarta province and around.

In Indian wedding, the women also have priority to make and hold the wedding party. The women have to prepare all kind of the party. The man just has to receive the decision of the women family. He cannot impinge that custom. The causes of this forbidden can make the woman get bad thing in the next time. One of it may be the death of the bride.

In this case, Mr. Webb forbids George to meet Emily before wedding day in the church for some days. According to him, it is a custom and becoming the social rules. It can cause a bad implication for the bride in the next time if it is being ignored. This myth, Mr. Webb said in the play, is believed for long time ago by the apeman. The reason is if groom sees the bride some days before wedding, it can cause the bad effects to the bride, such as the death or falling illness.

Mr. Webb also warns George to not make the wedding by himself. For him, the groom cannot make the wedding party. The party is the authority of bride's family. If this is not avoided, it will make the woman get bad thing such as the death.

From those myths we can take a goodness and advantage. The prohibition of groom to meet the bride functions to make the wedding party run well, because it is the common that if the groom visits the bride before wedding, the bride will be nervous in the main ceremony. About the holding of party, it is maybe to make cooperation between the groom's family and bride's family, because usually the groom prefers to prepare the other duty than the party. Beside that, the bride concentrates to the party preparation.

\section{Do not make the wedding party on} May

American wedding has mythological and historical precedents. The month of wedding party is a crucial decision. When the American would like to make wedding party, they usually discuss to decide the exact month. According to them, only certain months, depending on the couple's culture, are acceptable. Some American people say, "When December's shower falls fast, Mary and true love will last". Basic theme of this folktale includes the enchantment motif of marriage.

The wedding is symbolizing the transfer of a woman to her husband's family, wedding follow a prescribed set of rituals and superstitions that people believe will ensure happiness and safety for the couple. The wedding is momentous events. In the South America, the wedding ceremonies and celebrations have been shaped by traditional beliefs and practices that affirm marriage as an occasion for familial and communal celebration. 
About months, June, October and December are believed as the good months to hold the wedding party, particularly on June. But May constantly remains the worst month. June is the best month, going back to the days of Rome and the worship of Juno, the wife of Jupiter, who was patroness of the young and goddess of marriage. May is named for Maia, the goddess of growth and patroness of the old, and is the month that honors the unhappy dead. So that, this month is assumed as the bad moment to make some happy events.

Juno is the goddess of Rome personifies a creative youth. She oversees birth, both on a human and on a heavenly level. Upon beginning labor, women call upon Juno Lucina who has brought to the light, who is honored at the Matronalia of 1 March. Juno Cocella is the patroness, along with Janus. In Roman history, Juno intervened in several instances. Juno paired with Jupiter who is honored as the supreme god.

One of the popular American folktales about the danger of May is "Ghost Train". This story is about marriage couple that gets painful during his on May. This tragedy happened in May 1908. From this folktale, many traditional American believed that May is really the danger month. It is not good to do some special events, especially the wedding party.

It is told that the Grovers' conduct the wedding not on May. Example like the wedding of George and Emily that conducted on July considered as the save wedding for it escape the woe of their life. They believe that May is unlucky month for wedding. On May, the author of this play implicitly put it in act I containing the daily activity of
Grover's Corner. Act II, or we call as the act of wedding, is made as the activity of wedding. The author would like to say in this play that at that time American traditional people still believe that May is not good to be the day of wedding.

From this myth, maybe we cannot take many good things; we just get information that we have to take a care in deciding the wedding party day. It is like in every culture in many countries. There must be minimally one month that is indicated as the danger of month. We can take the example of the Javanese culture. For Javanese people, there is one month indicated as bad month to do anything special. It was called "Bulan Sapar". Usually, they ignore to make ceremony in that month.

\section{Wedding party in the afternoon}

In the American culture, many people will attend the wedding. It is because that event is the important moment of some body to begin new life with his couple. To come at the party, of course, people have difficulties, because of their daily activities during all day. But that was not all; the holding of wedding party in the afternoon has also the myth. According to the traditional belief, to hold the wedding party in the evening can bring a bad effect for the couple of marriage in the next.

The belief of wedding party that should hold in the afternoon actually follows the government of English clergy in the $17^{\text {th }}$ century. The government forbad the citizen to conduct the wedding in the morning, because the bridegroom tended to appear unready condition like the dirty and neglected dress of couple. So it is impossible to conduct the wedding in such massy condition. 
The government at that time also forbad the people to make wedding party in the evening, because the priest stated with a serious advice that wedding party in the evening can take the bridal couple of by sheer force to the alehouse frequently. These traditions of wedding in the morning and evening run in the United State continually. Even though these tradition are taken from English clergy in the $17^{\text {th }}$ century, but the American cannot eschew from the England tradition.

In Our Town, George and Emily conduct the wedding in the afternoon. The Grover's believe that it is better to hold the wedding party at noon than at morning or evening. This play gives us a massage implicitly that the wedding at noon will bring its couple to the beautiful sight. Besides, this case will lead the couple to the lucrative life. On the contrary, to conduct the wedding in the morning or evening will lead the couple to the woe and sorrow.

From this myth we can get the positive thing. The afternoon is the better time to hold the wedding than morning and evening. In the afternoon usually people are at home. They have just come from working. In the morning many people is very busy. It is also in the evening. At that time the people is very tired because of the daily activity in full day. So, the exact day to hold wedding ceremony is in the afternoon.

\section{Weather on the wedding day}

In the Ozarks and other parts of the South America, some people still believed that it was unlucky to marry when it was snowing or raining. In Maryland, snows means that the bride couple will get a dollar for every flake that falls on them. The rain falls when wedding day holds means that the bride will shed a tear for each raindrop. This is told in story the Wife of Bath in Chaucer's Canterbury Tales, who was got many troubles in her life because she held wedding when the rain was falling down. This tale is very popular in America and England.

In some lands, there are beliefs talking about the weather in the wedding day. Below is the superstition from Illinois, Massachusetts, and Alabama. Those lands, or now becoming the state, are the places that have many myths.

$\begin{array}{ll}\text { Illinois: } & \text { "If it snows on } \\ & \text { the wedding } \\ & \text { day, the } \\ & \text { husband will } \\ & \text { be good to his } \\ & \text { wife." } \\ \text { Massachusetts: } & \text { "Thunder } \\ & \text { during a a } \\ & \text { wedding is a } \\ & \text { sign of } \\ & \text { unhappiness } \\ & \text { all one's } \\ & \text { married life." } \\ & \text { "If you marry } \\ \text { on a pretty } & \text { on ay, you will } \\ & \text { dive happy." }\end{array}$

The tradition of weather persists in the United States and certainly with no knowledge or remembrance of Juno and Maia in Rome period or around $17^{\text {th }}$ century English clergy. At that time the people said:

Happy the bride

The sun shined on,

Woe to the bride

The rain rains on.

In the other variety of rhymes, the saying above can be said such as;

Happy is the bride the sun shined on, 
Tears for the bride the rain falls on.

In Our Town, the wedding of George and Emily was holding in good weather. The sun shines on. There was no rain and thunder at that time. The Grover's were attending. The wedding was running well. Consequently, -of course it is according to the myth- George and Emily live happy and full of grace. They lived in the beautiful small town. George would work in the garden and farm; Emily became the mother of his children.

Nobody will want to get the rain or thunder on his wedding party day. The positive thought from this myth is the wish to get the beautiful wedding day. We have to carefully choose the season. The weather usually is influenced by the season of that month. We have to learn the condition of the weather. Moreover, we should look for the information of the weather from the Geophysics and Meteorology Board. In Indonesia, that board is called as BMG. In every city we can find it.

The rain and thunder will make the ceremony not to be beautiful view. If we find the rain in the man's wedding party, of course the ceremony will be crowded, panic, and broken. To avoid them, the traditional people sometimes use magic, but it is probably uncommon for modern society.

\section{Color of dresses can be the symbol of good or bad effects}

The dress of bride is one of the important instruments of wedding. The guests usually pay their attention to the gown of bride. In American culture the gown symbolizes the beauty of the bride. In American mythology the color of the bride has certain meanings.

The wedding gown's color is especially crucial to depict chastity. One of the general colors used by American people is white. The popular rhymes noted; "Married in white, you have chosen all right", but warn, "Married in pink, your fortunes will sink." It means that it is really good to wear the white gown instead of other colors, and later rhyme told that it is so dangerous to wear the pink gown, as it will guide to the sink of home family.

To know completely the myths of color of bridal couple dresses, we can see the rhymes below with their meanings:

Married in blue, love ever true,

Married in white, you've chosen right,

Married in red, you'll wish yourself dead,

Married in black, you'll wish yourself back,

Married in gray, you'll go far away,

Married in brown, you'll live out of town,

Married in green, ashamed to be seen,

Married in pink, of you only he'll think,

Married in pearl, you'll live a whirl,

Married in yellow, jealous of your fellow,

Married in lavender, you'll always be savage.

In one old Scotland, there is a ballad talking about the dress of bride. That ballad titles "Bridal Dress", containing the belief and superstition of wedding. The main of message of that ballad is like rhymes above that we will be better-one of them- to use the white dress, because the color of 
white has a good symbolic and can come a lucky.

In Our Town, as the bride, Emily wears the white dress in her special day. She makes the white to be a good looking. She and Grover's still believe that the white dress can be a sign of lucky in the next time. In modern American society now, many people also do like that. They choose the white to be the bride's dress. One of the reasons is because the white is the bright color. Wearing the white dress looks more comfortable than other color.

\section{Ghost of death people will come to their family}

Every person must be dead. This life is just a moment. They will pass away and gather with other death people. They will get a responsibility into the God. The American traditional family who was passed away usually makes a various rites to help them in meeting to the God. The various rites will hold in the house after the death. Some of the death was pleasant and even amusing to look upon family in her lifetime.

Many people are homeless to anyone with a clear conscience, but some are vengeful and malevolent and return to torture their victims eternally. Often the ghosts of dead lovers or husbands and wives return to haunt their faithless sweetheart or spouse. Sometimes a parent comes back to make life unpleasant for his or her children; on other occasions the ghost returns to slay a wicked person or take revenge on the person who murdered, injured, or cheated him or her.

In American tales there are many folktales talking about the death people who come back to people life in the earth. One of them is To Life! written by Robert Kosmicki. The story is from Poland. One grandfather had just died about years ago at the age of ninety-five. He was a very wise man, but was kind of a boozer all his life. When he was a life, he ever told to his wife to buy a bottle of whisky for his birthday. On his birthday but he was death, his wife bought the bottle of whisky. The wife actually would like to know about the causes of the death of his husband's brother. On good time, the ghost of his husband attends to her house and told to his wife who killed his brother (Zeitin, 1982, 57).

In legend, American has tale like "Ghost Handprints". This story reveals that the death persons can understand and know what the life people feel. Sometimes they can attend to the earth and meet the life people. In stories of folk, the topic about ghost has many titles. It is also recognized until now that many American drama and film talking about the ghost.

In Our Town told that Emily was death because of her second bearing. She met her parent in law, Mrs. Gibbs and other Grover's. She lived in life after, or we can call that as the ghost. Then she asked to "the Angle" -in the play was recognized by Stage Manager- for living again and could meet her family even though just a moment. She shows that many things were left over there. He then permits her to return in the earth, and give options what day she wants. So she chooses her birthday to be the day she is coming back in the earth.

She returns to live on her birthday on February 11, 1899. She met her family in happy day. She would like to tell to her mother, Mrs. Webb, about something done in the next time. But this was just an 
illusion, because her return to the earth was just to know about people life, not to remind their problems.

In this case, the myth of ghost actually is very popular in the traditional American. Some people who were death will be the ghost. And the special day to know about their condition or to meet them is on the day of their birth. It is caused that in American culture; annual celebrations of the anniversary of the date of someone's birth are sometimes marking significant points in the life cycle. Birthdays are celebrated most often in family setting, but also at school and in the workplace (Brunvand, 1996: 85). It means that in some special day, not only birthday, the ghost of our family will come to our house.

Death is a phase in this rite, but only as a preparation for rebirth. In a sense, on her return, Emily was reborn, but he cannot remain with those who have not been born again. Her rebirth, according to Thomas E. Porter in his assay, includes the ability to communicate with the world and to the world the wisdom he has acquired. From her perspective on the other side of the grave, Emily tries to communicate her sense of communion to her mother. She sees her family together now and fragmented by separation in the future. Her mother cannot really look at her. There is no moment of communion because she does not share Emily's consciousness.

Human death is the result of conflict among divine being. Death is the result of man being cheated by a god or some other mythic being, or of the carelessness or stupidity of such a being. Death is the result of some human shortcoming, sometimes a rather futile one in our eyes. "The dead" have not died at all. The people who were dead have just "passed on".

\section{CONCLUSION}

American mythology has many sources; they are from tribes of Native American and Europe countries like Rome, England, Germany, Span, French, and so forth, which have come to the American land since hundreds years ago. It seems clearly that the Europe people influence American society in the early twentieth-century myths. The myths trusted by the Native American are difference with the myth trusted by the American society in the early twentiethcentury. The myths of Native American are talking about the stories of the deities.

On the other side, the American society myths in the early twentiethcentury reveal about beliefs and superstitions. For instance, if we take the story of myth origins, the beliefs and superstition are from the American folklores. The folklores themselves are divided into folktales, legends, folksongs, and fables. The values on the folklores could give the American a good attitude in doing something. Even the myths are not religious teaching, but those could be a support for their life to do the best. American society believed in them to be a custom so it is also called as the culture.

The myth values in Our Town play are talking about life attitudes. They are about the values of childhood, marriage, and death. The Grover's Corner on the play is a picture of the traditional American in the early twentieth-century, which still lived under religious and myth teaching. They made both of them as the life rules that must be trusted in their life. The positive thing in believing myth is how they can live peacefully and happily. In myths, they could find the positive thing. Even 
it was not really rational, but the purpose of the myth values is for the goodness.

The early twentieth-century, or during 1900s, was the American industrialization period so that it is only the traditional American who just still believed the myths. The modern American was very secular. They just believed something rational. The traditional American lived in small town and some village in the south and north of America. One of them lived in New Hampshire, in which at that time there are still many villages and small town has the traditional people.

Thornton Wilder in Our Town described the small town named Grover's Corner in which the society still did daily activities based on the custom. He just wanted to make Our Town as a representation of traditional American society at that time. In life of play, Wilder would like to say that in our life there are three phases of life we should pass; they are childhood, marriage, and death.

The myths of childhood, marriage and death in Our Town reveal the American beliefs and superstitions. The beliefs actually are very difficult to take the origins, because they are not only from the Native American, but also have been influenced by the other country values. Besides, the myths are not from the whole stories, but they are taken from part of the story. The main myth values on childhood, marriage and death are talking about how we carefully do something about them.

American actually has many myths correlated with those phases. In American folklore we can find the thousands of stories and messages about that. It is because childhood, marriage, and death are the important central of life. Many myth values are containing about that. Of course, it does not mean that in the other side the American does not have myths. In the action of politics, economics, science, literature, and soon, the American society also have myths, but here in this paper the writer does not mention and focus it.

\section{REFERENCES}

Brunvand, J. H. (ed). (1996). American Folklore: An Encyclopaedia. New York: Garland Publishing, Inc.

Carlsen, G. R. (ed). (1937). America Literature: Themes and Writers. New York: Mcgraw-Hill Book Company.

Coupe, L. (1997). Myth. London: Clays Ltd., St. Ives PLC.

Eliade, M. (1971). The Myth of The Eternal Return or Cosmos and History-translated by Willard R Trasa. New York: Princeton University Press.

Eliade, M. (1960). Myths, Dreams, and Mystery-translated by Philip Mairet. London: Great Britain Collins By Harvill Press.

Eliade, M. (1959). The Sacred and The Profane-translated by Willard R Task. New York: Harcourt, Brace and World Inc.

Endraswara, S. (2004). Metodologi Penelitian Sastra. Yogyakarta: Penerbit Pustaka Widyatama.

Fokkema, D. W., \& Kunne-Ibsch, E. (1977). Twentieth-Century Literary Theories, London: C. Hurst and Co.

Goff, P., \& Harvey, P. (ed). (1961). Religion and American Culture. London: The University of North Carolina Press.

Porter, T. E. (1969). Myth and Modern American Drama. Canada: Eayne State University Press.

Robinson, H. S., \& Wilson, K. (1978). Myths and Legends of All Nation. New Jersey: Littlefield, Adam and Company. 
Saliba, J. A. (1976). Homo Religiosus in Mircea Eliade, An Anthropological Evaluation, Leiden: E.J. Brill.

Teeuw, A. (2003). Sastera dan Ilmu Sastera. Jakarta: Pustaka Jaya.

Wilder, T. (1961). Three Plays by Thornton Wilder: Our Town, The
Skin of Our Teeth, The Matchmaker, New York: Bantam Books.

Zeffri. (1998). Manusia, Mitos dan Mitologi. Jakarta: Fakultas Sastra Universitas Indonesia. 